\title{
Front Matter: Volume 6635
}

, "Front Matter: Volume 6635," Proc. SPIE 6635, Advanced Topics in Optoelectronics, Microelectronics, and Nanotechnologies III, 663501 (31 May 2007); doi: 10.1117/12.746752

Event: Advanced Topics in Optoelectronics, Microelectronics, and SPIE. Nanotechnologies III, 2006, Bucharest, Romania 


\title{
PROCEEDINGS OF SPIE
}

\section{Advanced Topics in Optoelectronics, Microelectronics, and Nanotechnologies III}

\author{
Ovidiu lancu \\ Adrian Manea \\ Paul Schiopu \\ Editors
}

24-26 November 2006

Bucharest, Romania

Organized by

Politehnica University of Bucharest, Faculty of Electronic, Telecommunication and Information

Technology, Optoelectronics Research Center (Romania)

SPIE Romania Chapter

Sponsored by

SPIE Romania Chapter

Romanian Ministry of Education and Research

Electromagnetica Goldstar S.R.L. (Romania)

Optokon Romania S.R.L. (Romania)

Published by

SPIE-The International Society for Optical Engineering

Volume 6635

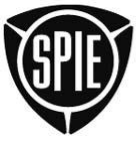


The papers included in this volume were part of the technical conference cited on the cover and title page. Papers were selected and subject to review by the editors and conference program committee. Some conference presentations may not be available for publication. The papers published in these proceedings reflect the work and thoughts of the authors and are published herein as submitted. The publisher is not responsible for the validity of the information or for any outcomes resulting from reliance thereon.

Please use the following format to cite material from this book:

Author(s), "Title of Paper," in Advanced Topics in Optoelectronics, Microelectronics, and Nanotechnologies III, edited by Ovidiu Iancu, Adrian Manea, Paul Schiopu, Proceedings of SPIE Vol. 6635 (SPIE, Bellingham, WA, 2007) Article CID Number.

ISSN 0277-786X

ISBN 9780819467799

Published by

SPIE-The International Society for Optical Engineering

P.O. Box 10, Bellingham, Washington 98227-0010 USA

Telephone 1 360/676-3290 (Pacific Time) · Fax 1 360/647-1445

http://www.spie.org

Copyright (C) 2007, The Society of Photo-Optical Instrumentation Engineers

Copying of material in this book for internal or personal use, or for the internal or personal use of specific clients, beyond the fair use provisions granted by the U.S. Copyright Law is authorized by SPIE subject to payment of copying fees. The Transactional Reporting Service base fee for this volume is $\$ 18.00$ per article (or portion thereof), which should be paid directly to the Copyright Clearance Center (CCC), 222 Rosewood Drive, Danvers, MA 01923. Payment may also be made electronically through CCC Online at http://www.copyright.com. Other copying for republication, resale, advertising or promotion, or any form of systematic or multiple reproduction of any material in this book is prohibited except with permission in writing from the publisher. The CCC fee code is 0277 $786 \times / 07 / \$ 18.00$.

Printed in the United States of America. 


\title{
Contents
}

ix Conference Committees

xi Introduction

\section{PLENARY SESSION}

663502 Experimental diagnostics of white-light vortices (Invited Paper) [6635-01]

O. V. Angelsky, O. P. Maksimyak, P. P. Maksimyak, Chernivtsi National Univ. (Ukraine);

I. Gruia, Bucharest Univ. (Romania)

663503 Nanometrology of microsystems: traceability problem in nanometrology (Invited Paper) [6635-02]

I. Iordache, D. Apostol, National Institute for Lasers, Plasma and Radiation Physics

(Romania); O. Iancu, G. Stanciu, Politehnica Univ. of Bucharest (Romania); P. C. Logofatu,

V. Damian, F. Garoi, National Institute for Lasers, Plasma and Radiation Physics (Romania);

B. Savu, Politehnica Univ. of Bucharest (Romania); M. Bojan, National Institute for Lasers,

Plasma and Radiation Physics (Romania)

663504 Theoretical and numerical analysis of the microring resonator refractometers (Invited Paper) [6635-03]

M. Kusko, D. Cristea, IMT-Bucharest (Romania)

\section{NANOSCIENCE AND NANOENGINEERING}

663505 Absorption and photoluminescence of Ga-La-S:O and Ga-Ge-As-S glasses doped with rare-earth ions (Invited Paper) [6635-04]

M. S. Iovu, A. M. Andriesh, N. N. Syrbu, Ctr. of Optoelectronics, IAP (Moldova); A. B. Seddon, D. Furniss, Univ. of Nottingham (United Kingdom); G. J. Adriaenssens, Univ. of Leuven (Belgium); Yu. S. Tver'yanovich, St. Petersburg State Univ. (Russia)

663506 Optical encoder measurement technology [6635-05]

I. Iordache, M. Bojan, D. Apostol, V. Damian, F. Garoi, P. C. Logofătu, National Institute for Lasers, Plasma and Radiation Physics (Romania); R. Muller, National Institute in Microtechnologies (Romania); B. Savu, Univ. Politehnica of Bucharest (Romania)

\begin{abstract}
Pagination: Proceedings of SPIE follow an e-First publication model, with papers published first online and then in print and on CD-ROM. Papers are published as they are submitted and meet publication criteria. A unique, consistent, permanent citation identifier (CID) number is assigned to each article at the time of the first publication. Utilization of CIDs allows articles to be fully citable as soon they are published online, and connects the same identifier to all online, print, and electronic versions of the publication.

SPIE uses a six-digit CID article numbering system in which:

- The first four digits correspond to the SPIE volume number.

- The last two digits indicate publication order within the volume using a Base 36 numbering system employing both numerals and letters. These two-number sets start with 00, 01, 02, 03, 04, 05, 06, 07, 08, 09, 0A, OB ... 0Z, followed by 10-1Z, 20-2Z, etc.
\end{abstract}

The CID number appears on each page of the manuscript. The complete citation is used on the first page, and an abbreviated version on subsequent pages. 
663507 Enhancements of the Abelés method for refractive index determination [6635-06] P. C. Logofătu, I. M. Iordache, M. M. Bojan, National Institute for Lasers, Plasma and Radiation Physics (Romania)

663508 GHz sense amplifier for MRAM [6635-07]

I. Schiopu, O. Iancu, Optoelectronic Research Ctr., Politehnica Univ. of Bucharest (Romania)

663509 Light induced phenomena in amorphous As $100-x$ Se $_{x}$ and As40Se $60: S n$ thin films [6635-08] M. A. lovu, M. S. lovu, D. V. Harea, E. P. Colomeico, V. G. Ciorba, Ctr. of Optoelectronics, IAP (Moldova)

66350A Hardware simulator for design and characterization of MOEMS for environmental applications [6635-09]

F. Caldararu, ECOSEN Ltd. (Romania) and Ecological Univ. from Bucharest (Romania);

A. Vasile, Politehnica Univ. of Bucharest (Romania); M. Caldararu, ECOSEN Ltd. (Romania)

66350B Fault tolerant techniques for integrated circuits in submicron and nanotechnologies [6635-10]

A. Bacivarov, EUROQUALROM, Univ. Politehnica of Bucharest (Romania)

66350C Polarization properties of volumetrical and surface scattering of optically heterogeneous media [6635-11]

A. D. Arkhelyuk, L. I. Podkamen, Chernivtsi National Univ. (Ukraine)

\section{PHYSICAL OPTICS AND SIGNAL PROCESSING}

66350D The reduction of the physical inputs number to optoelectronic logical gates [6635-12] V. Degeratu, O2Micro Romania (Romania) and Univ. Politehnica of Bucharest (Romania); P. Şchiopu, Univ. Politehnica of Bucharest (Romania) and Optoelectronic Research Ctr., Politehnica Univ. of Bucharest (Romania); Ş. Degeratu, O2Micro Romania (Romania) and Univ. Politehnica of Bucharest (Romania)

66350E Study of speckle-field dynamics scattered by surface of concrete during congelation [6635-13]

M. P. Gorsky, A. P. Maksimyak, P. P. Maksimyak, Chernivtsi National Univ. (Ukraine)

66350F Optical bistability of layer semiconductors in the exciton absorption region [6635-14] C. Yu. Zenkova, V. M. Kramar, N. K. Kramar, Chernivtsi National Univ. (Ukraine)

$66350 \mathrm{~A}$ global study about optical 4f image processing filters [6635-15]

T. Florin, Technical Univ. of Cluj Napoca (Romania)

66350H Simple LSI image acquisition system analysis [6635-16]

T. Florin, Technical Univ. of Cluj Napoca (Romania)

663501 Control charts for non-Gaussian distributions [6635-17]

F. Babus, Univ. of Angers (France) and EUROQUALROM, Univ. Politehnica of Bucharest (Romania); A. Kobi, Th. Tiplica, Univ. of Angers (France); I. Bacivarov, A. Bacivarov, EUROQUALROM, Univ. Politehnica of Bucharest (Romania) 
66350J Young's diagnostics of phase singularities into polychromatic light fields (Invited Paper) [6635-18]

O. O. Arkhelyuk, C. V. Felde, H. V. Bogatyryova, P. V. Polyanskii, Chernivtsi National Univ. (Ukraine)

\section{LASER AND BIOMEDICINE}

66350K Polarization speckle-reconstruction of biological tissues architectonics: Part 1. Polarization correlometry of birefringence architectonics: singular approach (Invited Paper) [6635-19] A. O. Angelskaya, Yu. A. Ushenko, Ye. Ushenko, A. G. Ushenko, Yu. Ya. Tomka, Chernivtsi National Univ. (Ukraine)

66350L Polarization phase reconstruction of biological tissue architectonics: Part 2. Study of polarizing intercorrelative function of coherent images of phase-inhomogeneous layer anisotropy (Invited Paper) [6635-20]

A. O. Angelskaya, A. G. Ushenko, Yu. A. Ushenko, A. Dubolazov, V. Istratiy, Yu. Ya. Tomka, Chernivtsi National Univ. (Ukraine)

$66350 \mathrm{M}$ Polarization phase reconstruction of biological tissue architectonics: Part 3. Polarizingcorrelative processing of images of statistical objects in the problem of visualization and topology reconstruction of their phase heterogeneity (Invited Paper) [6635-21]

A. O. Angelskaya, A. G. Ushenko, Yu. A. Ushenko, A. Dubolazov, V. Istratiy, Yu. Ya. Tomka, Chernivtsi National Univ. (Ukraine)

66350N Polarization phase reconstruction of biological tissue architectonics: Part 4. Coherent introscopy of phase-inhomogeneous surface and layers (Invited Paper) [6635-22] A. O. Angelskaya, A. G. Ushenko, Yu. A. Ushenko, A. Dubolazov, V. Istratiy, Yu. Ya. Tomka, Chernivtsi National Univ. (Ukraine)

663500 Polarization singularities of biological objects speckle-fields [6635-23] O. Angelsky, A. Ushenko, S. Yermolenko, Y. Ushenko, A. Prydij, Y. Ushenko, Chernivtsi National Univ. (Ukraine)

$66350 \mathrm{P}$ The techniques and results of biocorrectors energy-informational influence registration [6635-24] M. S. Gavrylyak, P. P. Maksimyak, L. J. Podkamen, Chernivtsi National Univ. (Ukraine)

66350Q Refractive index measurement using comparative interferometry [6635-25] M. Bojan, D. Apostol, V. Damian, P. C. Logofatu, F. Garoi, I. Iordache, National Institute for Lasers, Plasma and Radiation Physics (Romania)

66350R Study of light-scattering by ferronematic suspension [6635-26] A. L. Nehrych, P. P. Maksimyak, Chernivtsi National Univ. (Ukraine)

663505 Analysis of conversion efficiency of internal second-harmonic generation in InGaAs quantum-well laser diodes emitting around $960 \mathrm{~nm}$ [6635-27]

F. Puntaru, N. N. Puscas, Univ. Politehnica of Bucharest (Romania) 
66350T Interference diagnostics large-scale surfaces [6635-28]

O. V. Angelsky, O. P. Maksimyak, P. P. Maksimyak, Chernivtsi National Univ. (Ukraine)

$66350 \mathrm{U}$ Surface-barrier sensors on basis of zinc selenide [6635-29]

V. P. Makhniy, L. I. Arkhilyuk, V. V. Mel'nyk, Yuriy Fedkovych Chernivtsi National Univ. (Ukraine)

66350V Time-averaged vibration mode viewing with DSPI [6635-30]

F. Garoi, D. Apostol, A. Sima, V. Damian, P. C. Logofătu, V. Nascov, I. lordache, M. Bojan, National Institute for Lasers, Plasma and Radiation Physics (Romania)

66350W CMOS integrated structures with optical sensors [6635-31]

E. Sofron, P. Vulpoiu, P. Burciu, Univ. of Pitesti (Romania)

66350X Autonomous remote sensing with SAW devices [6635-32]

O. Iancu, P. Schiopu, A. Manea, I. Cristea, N. Grosu, Politehnica Univ. of Bucharest (Romania)

66350Y The detection limit of magnetic microsensors [6635-33]

C. Panait, G. Căruntu, Maritime Univ. of Constantza (Romania)

$66350 Z$ The optimization of magnetic sensitive MOSFET structures [6635-34]

G. Căruntu, C. Panait, Maritime Univ. of Constanta (Romania)

663510 Preparation and characterization of indium tin oxide films by sol-gel method [6635-35]

A. Ciuciumis, I. Cernica, National Institute for Research and Development in

Microtechnologies (Romania)

663511 Synthesis of yttrium aluminium garnet doped with cerium for application in a new generation luminescent lighting devices [6635-36]

V. Schiopu, National Institute for Research and Development in Microtechnologies (Romania); M. Macrin, S.C. Microelectronica S.A. (Romania); I. Cernica, National Institute for Research and Development in Microtechnologies (Romania)

\section{OPTICAL COMMUNICATION, MODELING, AND SIMULATION}

663512 A survey of two-dimensional codes for optical CDMA [6635-37]

P. Stroica, Univ. Politehnica of Bucharest (Romania); M. VladesCu, Electromagnetica Goldstar Ltd. (Romania); O. Iancu, Univ. Politehnica of Bucharest (Romania)

663513 Advanced methods for electromagnetic investigation of PCB/PWB layouts [6635-38] N. D. Codreanu, C. Ionescu, P. Svasta, V. Golumbeanu, Politehnica Univ. of Bucharest (Romania)

663514 Design of Optoelectronics Research Center website [6635-39]

P. R. Nicolae, Politehnica Univ. of Bucharest (Romania); P. Schiopu, Politehnica Univ. of Bucharest (Romania) and Optoelectronic Research Ctr., Politehnica Univ. of Bucharest (Romania) 
663515 GSM-Railway as part of the European rail traffic management system [6635-40] I. Bibac, Nortel (France)

663516 Study of dynamic coherent light-scattering in the process of phase transition in liquid crystals [6635-41]

M. S. Gavrylyak, P. P. Maksimyak, Chernivtsi National Univ. (Ukraine)

663517 Defect and fault modelling of a CMOS n-diffusion photodiode [6635-42]

A. Drăgulinescu, Optoelectronics Research Ctr., Politehnica Univ. of Bucharest (Romania); L. Lizarraga, S. Mir, G. Sicard, TIMA Lab. (France)

663518 Wavelength division multiplexing WDM, CWDM, and DWDM applications [6635-43] I. B. Vasile, National Communications Research Institute (Romania); A. Vasile, Politehnica Univ. of Bucharest (Romania); S. Luciana, National Communications Research Institute (Romania); M. Tache, Politehnica Univ. of Bucharest (Romania)

663519 Simulation design in Java for digital image processing [6635-44] M. Kadar, I. lleană, 1 Decembrie 1918 Univ. of Alba Iulia (Romania)

66351A Modeling of electromagnetic fields reflected by runes [6635-45] O. P. Maksimyak, L. Y. Podkamen, Chernivtsi National Univ. (Ukraine)

66351B Admin interface of Optoelectronics Research Center [6635-46] P. R. Nicolae, Politehnica Univ. of Bucharest (Romania); P. Schiopu, Politehnica Univ. of Bucharest (Romania) and Optoelectronic Research Ctr., Politehnica Univ. of Bucharest (Romania)

$66351 \mathrm{C}$ Life testing of electronic components: a Bayesian approach [6635-47] S. Voiculescu, F. Guérin, Univ. d'Angers (France); I. C. Bacivarov, Politehnica Univ. of Bucharest (Romania)

$66351 \mathrm{D}$ Evaluation of the attenuation and the optical coupling between optical fibers and waveguides [6635-48]

S.. Ghinoiu, Univ. Politehnica of Bucharest (Romania); L. A. Puscas, E. M. Rotaru, R. Galatus, Technical Univ. of Cluj-Napoca (Romania); N. N. Puscas, Univ. Politehnica of Bucharest (Romania)

66351E General artificial neuron (Invited Paper) [6635-49]

V. Degeratu, O2Micro Romania (Romania) and Univ. Politehnica of Bucharest (Romania): P. Şchiopu, Univ. Politehnica of Bucharest (Romania) and Optoelectronic Research Ctr., Politehnica Univ. of Bucharest (Romania); Ş. Degeratu, O2Micro Romania (Romania) and Univ. Politehnica of Bucharest (Romania)

66351F The spatial coding of intensity into neural network [6635-50]

V. Degeratu, O2Micro Romania (Romania) and Univ. Politehnica of Bucharest (Romania); P. Şchiopu, Univ. Politehnica of Bucharest (Romania) and Optoelectronic Research Ctr., Politehnica Univ. of Bucharest (Romania); Ş. Degeratu, O2Micro Romania (Romania) and Univ. Politehnica of Bucharest (Romania) 
$66351 \mathrm{G}$ Estimation of the influence of the shape and size of nonspherical particles in polarized light [6635-51]

A. D. Arkhelyuk, L. I. Podkamen, Chernivtsi National Univ. (Ukraine); I. Gruia, Bucharest Univ. (Romania)

Author Index 


\title{
Conference Committees
}

\author{
Conference Manager \\ Ionica Cristea, Politehnica University of Bucharest, Optoelectronic \\ Research Center (Romania) \\ Conference Chairs \\ Ovidiu Iancu, Politehnica University of Bucharest, Optoelectronic \\ Research Center (Romania) \\ Adrian Manea, Politehnica University of Bucharest, Optoelectronic \\ Research Center (Romania) \\ Paul Şchiopu, Politehnica University of Bucharest, Optoelectronic \\ Research Center (Romania) \\ Dan Cojoc, Politehnica University of Bucharest (Romania)
}

Scientific and Program Committee

Oleg V. Angelsky, National University of Chernovtsy, Ukraine

Dan Apostol, National Institute for Lasers, Plasma and Radiation Physics (Romania)

Henri Arsenault, Laval University (Canada)

lleana Cernica, National Institute for R\&D in Microtechnologies IMT (Romania)

Dan Cojoc, Politehnica University of Bucharest (Romania)

Dana Cristea, National Institute for R\&D in Microtechnologies IMT (Romania)

Eugene Curatu, Alcon Laboratories (USA)

Enzo Di Fabrizio, National Institute for Physics of Matter, TASC-INFM Trieste (Italy)

Vasile Dorogan, Technical University of Moldova, Chishinev (Moldova)

Marin Dragulinescu, Politehnica University of Bucharest (Romania)

Carlos Ferreira, University of Valencia (Spain)

Constantin Grigoriu, National Institute of Lasers, Plasma and Radiation

Physics (Romania)

Ovidiu lancu, Politehnica University of Bucharest (Romania)

Ioan Ileana, University of Alba-Iulia (Romania)

Mihail S. Iovu, Technical University of Moldova, Chishinev (Moldova)

Alexandru Lupascu, Politehnica University of Bucharest (Romania)

Adrian Manea, Politehnica University of Bucharest (Romania)

Ivo Montrosset, Politechnic of Turin (Italy)

Ion M. Popescu, Politehnica University of Bucharest (Romania)

Niculae N. Puscas, Politehnica University of Bucharest (Romania)

Adrian Rusu, Politehnica University of Bucharest (Romania)

Paul Şchiopu, Politehnica University of Bucharest (Romania)

George Stanciu, Politehnica University of Bucharest (Romania) 
Local Organizing Committee

Paul Şchiopu

Adrian Manea

Marilena Dan

Neculai Grosu

Alexandru Vasile

Session Chairs

$1 \quad$ Nanoscience and Nanoengineering

Mihail S. Iovu, Center of Optoelectronics, Chisinau (Moldova)

Dan Apostol, National Institute for Lasers, Plasma and Radiation Physics (Romania)

2 Physical Optics and Signal Processing

Claudia Yu. Zenkova, Chernivtsi National University (Ukraine)

Dana Cristea, Institute of Microtechnology, Bucharest (Romania)

3 Laser and Biomedicine

Oleg V. Angelsky, Chernivtsi National University (Ukraine)

Constantin Grigoriu, National Institute for Lasers, Plasma and Radiation Physics (Romania)

4 Environmental and Chemical Sensors

Emil Sofron, University of Pitesti (Romania)

Neculai Grosu, Politehnica University of Bucharest, Optoelectronic Research Center (Romania)

5 Optical Communication, Modeling and Simulation

Adrian Manea, Politehnica University of Bucharest, Optoelectronic Research Center (Romania)

Paul Şchiopu, Politehnica University of Bucharest, Optoelectronic Research Center (Romania) 


\section{Introduction}

On behalf of the organizers, especially in the name of professor lancu Ovidiu, Politehnica University of Bucharest, Optoelectronic Research Center, and president of the ATOMN 2006 Organizing Committee, I am pleased to welcome you to the third edition of the conference proceedings of Advanced Topics in Optoelectronics, Microelectronics, and Nanotechnologies, held 24-26 November 2006 in Bucharest Romania.

The field of micro- and nanotechnology in optoelectronics is a domain that has great scientific applications worldwide. Two years have passed since we last met in this hall and almost all of us who participated at the previous conferences are here again. We meet as scientists, engineers, and students to report on recent research results and educational approaches in this field.

The conference is organized into five main sections:

- Nanoscience and Nanoengineering

- $\quad$ Physical Optics and Signal Processing

- $\quad$ Lasers and Biomedicine

- Environmental and Chemical Sensors

- Optical Communications, Modelling and Simulation.

I would like to thank to the organizations that offered us assistance and support to organize this conference:

- SPIE Romania Chapter, especially to its president Constantin Grigoriu, Ph.D., for support in publishing the proceedings of this conference in the United States of America

- Ministry of Education and Research, Bucharest, Romania

- Electromagnetica-GoldStar, Bucharest, Romania

- $\quad$ Optokon Romania S.R.L.

Thanks also to the faculty of Electronics, Communications and Information Technology for support, and to all the staff of the Optoelectronics Research Center.

Paul Şchiopu 
Downloaded From: https://www.spiedigitallibrary.org/conference-proceedings-of-spie on 26 Apr 2023

Terms of Use: https://www.spiedigitallibrary.org/terms-of-use 